\begin{tabular}{|c|c|c|c|c|c|c|}
\hline \multirow{4}{*}{ Impact Factor: } & ISRA (India) & $=4.971$ & SIS (USA) & $=0.912$ & ICV (Poland) & $=6.630$ \\
\hline & ISI (Dubai, UAE & $=0.829$ & РИНЦ (Russia) & $=0.126$ & PIF (India) & $=1.940$ \\
\hline & GIF (Australia) & $=0.564$ & ESJI (KZ) & $=8.716$ & IBI (India) & $=4.260$ \\
\hline & JIF & $=1.500$ & SJIF (Morocco) & $=5.667$ & OAJI (USA) & $=0.350$ \\
\hline
\end{tabular}

\section{SOI: $1.1 /$ TAS $\quad$ DOI: $10.15863 /$ TAS \\ International Scientific Journal Theoretical \& Applied Science}

p-ISSN: 2308-4944 (print) e-ISSN: 2409-0085 (online)

Year: $2020 \quad$ Issue: 03 Volume: 83

Published: $01.03 .2020 \quad \underline{\text { http://T-Science.org }}$
QR - Issue

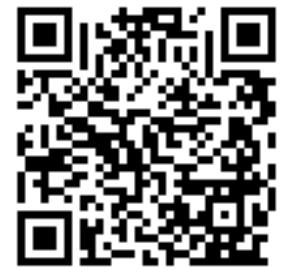

QR - Article

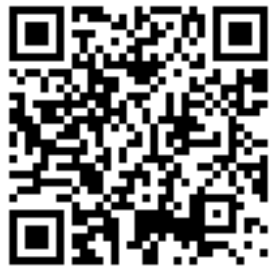

Konstantin Ivanovich Kurpayanidi Fergana polytechnic institute $\mathrm{Ph} \mathrm{D}$ in economics, Professor of the Russian academy of natural sciences, Fergana, Uzbekistan Corresponding member of the International Academy of

Theoretical \& Applied Sciences https://orcid.org/0000-0001-8354-1512 w7777@mail.ru

\title{
ON THE PROBLEM OF MACROECONOMIC ANALYSIS AND FORECASTING OF THE ECONOMY
}

\begin{abstract}
A new stage of reforms has begun in the Republic of Uzbekistan, characterized by deep and largescale transformations in all spheres of life and activity of the state. The action Strategy for five priority areas of the country's development in 2017-2021 was approved. Special attention is paid to issues of social and economic development, creating an open economy, healthy competition, reducing the state presence in the economy, achieving high rates of economic growth by diversifying the economy and increasing labor productivity, and implementing a stable monetary policy. A balanced macroeconomic policy is being implemented, which is aimed at maintaining a balance between social support for the population and stimulating the growth of economic sectors. The paper provides a deep system analysis of the dynamics of changes in some macroeconomic indicators in recent years. The issues of development of the main trade partners of Uzbekistan are considered. As a result of the study, the author identified the vectors of strategic directions for the national economy of Uzbekistan, and also proposed solutions to typical problems associated with projected economic growth.

Key words: macroeconomic analysis, macroeconomic indicators, consumer price index, inflation, forecast, economy of Uzbekistan, economic growth.

Language: English

Citation: Kurpayanidi, K. I. (2020). On the problem of macroeconomic analysis and forecasting of the economy. ISJ Theoretical \& Applied Science, 03 (83), 1-6.

Soi: http://s-o-i.org/1.1/TAS-03-83-1 Doi: crossef https://dx.doi.org/10.15863/TAS.2020.03.83.1

Scopus ASCC: 2000.
\end{abstract}

\section{Introduction}

In recent years, the economy of Uzbekistan has implemented fundamental measures for economic reform aimed at improving the efficiency of market mechanisms and strengthening private property.

Given the significantly increased number of working-age populations, the country's top priority is to create new jobs and improve working conditions. Uzbekistan has already implemented the first wave of important economic reforms, including liberalization of the currency market, tax reform and serious improvement of statistics. Faced with the need for large-scale structural reforms, the official bodies want to carry out reforms aimed at eliminating the distortions that cause the greatest damage to the economy of the country. The main challenge in the area of short-term macroeconomic stability is to prevent a credit boom that could cause excessive external deficits and increase inflationary pressures.

Degree of study of a problem. The study of the issue of forecasting development of the economy and economic growth, directions of development is typical for economists of various schools and individual researchers. The relationship between economic dynamics and growth rates was investigated by Joseph Alois Schumpeter [1], and the problem of public policy to stimulate national development was considered by Friedrich List [2]. Economists of the 


\begin{tabular}{|c|c|c|c|c|c|c|}
\hline \multirow{4}{*}{ Impact Factor: } & ISRA (India) & $=4.971$ & SIS (USA) & $=0.912$ & ICV (Poland) & $=6.630$ \\
\hline & ISI (Dubai, UAE & $=0.829$ & РИНЦ (Russia & $=0.126$ & PIF (India) & $=1.940$ \\
\hline & GIF (Australia) & $=0.564$ & ESJI (KZ) & $=8.716$ & IBI (India) & $=4.260$ \\
\hline & JIF & $=1.500$ & SJIF (Morocec & $=5.667$ & OAJI (USA) & $=0.350$ \\
\hline
\end{tabular}

institutional direction, developing the approach of $\mathrm{J}$. A. Schumpeter, noted the important role of the technological factor in economic growth, described the relationship between basic technologies and the nature of economic development of society. The study of the techno-economic aspects of economic development is devoted to the work of Thorstein Bunde Veblen [3], John Kenneth Galbraith [4], G.Dosi [5], John Bates Clark [6] and others within the "main current." Theoretical and practical aspects of economic growth were investigated by John Maynard Keynes [7], Evsey Domar [8], Roy Forbes Harrod [9], Robert Merton Colow [10], James Tobin [11], Edmund S. Phelps [12]. For the conditions of the transition economy, the works of L.I. Abalkin [13], V.V. Bokov [14], S.U. Glazyev [15], T. Koichuev [16], A. K. Koshanov [17], V.I. Kusshlin [18], K. I. Mikulsky [19], A.M. Rakhimov [20], A. I.Tatarkin [21] and others made a significant contribution to the study of the problem.

In Uzbekistan, various aspects of economic growth are reflected in the scientific works of I.I. Iskandarov, A.M. Kadyrov [22], A.F. Rasulev [23], G.K. Saidova [24], S.V. Chapel [25], D.V. Trostyansky [26], etc. The problems of achieving the economic development of independent States in the context of the transition period in domestic and foreign literature received wide coverage. However, these attempts, because of the complexity of the problems being solved, do not yet contain clear solutions to the practice of managing in the new conditions. A number of questions remain in the position of measures reflecting only certain stages in the cyclical development of the advanced States, but they did not concern the transitional economies, while others are based on the national and social characteristics of individual CIS countries and do not answer the most important problems of the quality of economic growth of transformation systems. Important aspects of this problem and, in particular, the content of the quality of economic growth, the ratio of the quality of growth to economic development, the definition of priorities of public policy regarding the problem of optimal growth, etc., remain insufficiently studied.

\section{Research methods.}

The study used statistical methods, empirical, systems and situational analysis.

\section{Materials and Methods}

For example, according to preliminary estimates, the State Committee on Statistics, the GDP of the Republic of Uzbekistan in January-December 2019 in current prices amounted to 58.3 billion dollars and, compared to January-December 2018, grew by $5.6 \%$ in real terms. The GDP deflator index against JanuaryDecember 2018 prices amounted to $119.2 \%$. GDP per capita was 1724 dollars and, compared to the corresponding period last year, increased by $3.6 \%$. Compared to the corresponding period last year, in the sectoral structure of GDP (VPS) the share of agriculture, forestry and fisheries decreased from 31.5 $\%$ to $28.1 \%$, services - from $35.9 \%$ to $35.5 \%$, while the share of industry increased from $26.5 \%$ to $30.0 \%$ and construction - from $6.1 \%$ to $6.4 \%$ [27].

The rate of economic growth for JanuaryDecember 2019 is due to positive dynamics in the main sectors of the economy. Gross value added created by all sectors of the economy amounted to $90.9 \%$ of total GDP and increased by $5.6 \%$ (contribution to GDP growth - 5.0 percentage points). Net taxes on products in the GDP structure amounted to $9.1 \%$ and showed growth at the level of $5.6 \%$ (contribution to GDP growth - 0.6 p.p.).

According to the results of January-December 2019, agriculture, forestry and fisheries showed a positive growth rate of $2.5 \%$. The contribution of this industry to GDP growth amounted to 0.7 p.p. The positive dynamics in agriculture, forestry and fisheries is related to the growth of crop production by $3.7 \%$ and livestock production by $1.7 \%$. There is a $6.6 \%$ increase in value added in the industry. At the same time, the positive contribution to GDP growth from industrial production amounted to 1.6 p.p. Positive dynamics in this industry is ensured due to growth of added value of mining industry and development of quarries by $1.9 \%$, manufacturing industry - by $8.9 \%$ and other industries - by $1.6 \%$.

One of the most important indicators of the System of National Accounts, which describes the final result of the productive activities of the resident economic units, which is measured by the value of goods and services produced by these units for final use, is GDP. His analysis is of particular interest in macroeconomics.

Macroeconomic analysis is the final stage of any statistical study. The analysis of economic development is usually carried out in order to identify the main relationships and proportions of social production; The extent to which individual factors influence economic performance; receiving theoretical conclusions; The feasibility and further improvement of the statistical methodology used; Formulation of practical conclusions on the main trends in socio-economic processes and their effectiveness.

Based on the peculiarities of the Republic and world experience, institutional reform of the country's economy has focused on advanced highly efficient enterprises. The aim of drawing up an adequate socioeconomic reality for the short-term development of the country is divided into a number of separate tasks involving difficulties of different types. The difficulties of macroeconomic forecasting are related not only to the fact that the global financial system is in a situation of post-crisis transformation, but also to the difficulty of finding analytical tools that could be used in the current situation. 


\begin{tabular}{|c|c|c|c|c|c|c|}
\hline \multirow{4}{*}{ Impact Factor: } & ISRA (India) & $=4.971$ & SIS (USA) & $=0.912$ & ICV (Poland) & $=6.630$ \\
\hline & ISI (Dubai, UAE & $=0.829$ & РИНЦ (Russia & $=0.126$ & PIF (India) & $=1.940$ \\
\hline & GIF (Australia) & $=0.564$ & ESJI (KZ) & $=8.716$ & IBI (India) & $=4.260$ \\
\hline & JIF & $=1.500$ & SJIF (Morocce & $=5.667$ & OAJI (USA) & $=0.350$ \\
\hline
\end{tabular}

- There are several methods of forecasting: first, the method of extrapolating earlier trends at the moment can have only limited application precisely because recent trends were in one way or another related to pre-crisis characteristics of economic dynamics.

- Second, the studies of economic cycle researchers cannot form the basis for short-term conclusions because of their fundamental orientation towards the synthesis of long-term data based on the analysis of the relevant time series.

- Third, the construction of mathematical models does not meet the task of forming a holistic understanding that is taking place: this method requires ignoring specific figures and events in the name of achieving the desired level of formalization of calculations and drawing conclusions.

A compromise seems to be found if the causal method of event series analysis and statistics is used for prediction purposes. At the same time, reliability of any conclusion is achieved at the same time due to its double check - statistical and actual.

The rapid restoration of entrepreneurial confidence in the availability of growth prospects is an obvious argument in favor of the thesis that microeconomic prerequisites (at the level of improving the motivation of entrepreneurs and increasing the financial stability of enterprises) for the modernization of the economy exist.

In the commodity structure of Uzbekistan's exports over the last 10 years (2008-2018) there have been changes towards a decrease in the share of cotton-fiber and an increase in the shares of food, energy and services. However, according to the analysis of the technicality of Uzbekistan's export structure, a significant share (about 60\%) of it continues to be occupied by raw materials and resource-intensive goods.

Table 1. Analysis of the main macroeconomic indicators (forecast) of the development of the Republic of Uzbekistan for 2019 and targets for 2020-2021.

\begin{tabular}{|l|l|c|c|c|}
\hline \multirow{2}{*}{$№$} & \multicolumn{1}{|c|}{ Indicators } & 2019 & \multicolumn{2}{c|}{ Target reference points on: } \\
\cline { 3 - 4 } & & & 2020 & 2021 \\
\hline 1 & Gross domestic product, billion sum & 511838 & 524105 & 637970 \\
\hline 2 & Gross domestic product growth rate, $\%$ & 105,6 & 106,0 & 107,0 \\
\hline 3 & Consumer price index by December last year, \% & 15,2 & 12,6 & 9.9 \\
\hline 4 & Industrial product growth rate, $\%$ & 106,6 & 106,2 & 107,2 \\
\hline 5 & $\begin{array}{l}\text { Growth rate of agricultural, forestry and fisheries } \\
\text { production farms, in \% }\end{array}$ & 102,5 & 103,4 & 103,4 \\
\hline 6 & Capital investment growth rate, $\%$ & 117,0 & 110,1 & 110,9 \\
\hline 7 & Retail trade turnover growth rate, $\%$ & 104,8 & 105,5 & 106,5 \\
\hline 8 & $\begin{array}{l}\text { Consolidated budget deficit (in \% of gross domestic } \\
\text { product and excluding the Fund for Reconstruction } \\
\text { and Development of the Republic of Uzbekistan) }\end{array}$ & $-1,8$ & $-0,8$ & 0,0 \\
\hline
\end{tabular}

According to preliminary estimates, the forecast of GDP of the Republic of Uzbekistan for 2020 will amount to 524,105 billion sum, and in 2021 - 637,970 billion sum respectively. GDP growth rate in 2020 will be $106.0 \%$, and in $2020-106.0 \%$ and in 2021 $107.0 \%$.

While maintaining the dynamics of dependence, the consumer price index of the Republic of Uzbekistan and, excluding the impact of changes in certain factors, the projected consumer price index for 2020 will be $12.6 \%$, and in 2021 the CPI - 9.9\%.
In recent years, the development of the national economy has taken place in the context of adaptation to the consequences of the global economic crisis, the slowdown in the growth of the world economy as a whole and the main trading partners of the country.

According to the latest data of the International Monetary Fund (IMF), in 2019-2023 the world economy will grow at a moderate rate of $3.8 \%$ per year on average. In 2019 in the main trading partners of Uzbekistan GDP growth will be: in Russia - 1.5\%, Kazakhstan - 2.8\%, China - 6.4\%, the European Union $-2 \%$. 


\begin{tabular}{|c|c|c|c|c|c|c|}
\hline \multirow{4}{*}{ Impact Factor: } & ISRA (India) & $=4.971$ & SIS (USA) & $=0.912$ & ICV (Poland) & $=6.630$ \\
\hline & ISI (Dubai, UAE & $=0.829$ & РИНЦ (Russia) & $=0.126$ & PIF (India) & $=1.940$ \\
\hline & GIF (Australia) & $=0.564$ & ESJI (KZ) & $=8.716$ & IBI (India) & $=4.260$ \\
\hline & JIF & $=1.500$ & SJIF (Morocco) & $=5.667$ & OAJI (USA) & $=0.350$ \\
\hline
\end{tabular}

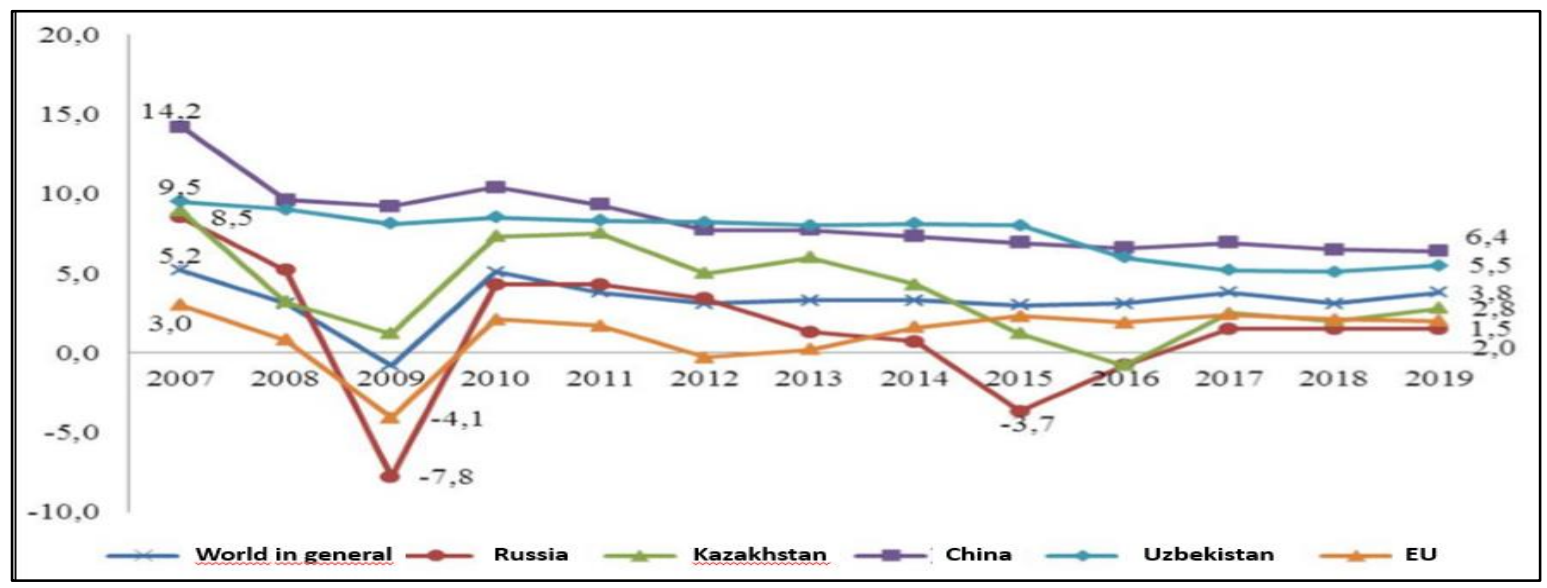

Figure 1 - Growth of the world economy and the main trading partners of Uzbekistan (in \%).

Energy prices have tended to rise over the past three years, according to the IMF. By the end of 2019, the average price of gold is expected to be $\$ 1,496,9$ per ounce or, with $2.4 \%$ growth, the price of crude oil will be $\$ 70.3$ per barrel and natural gas will be $\$ 106.5$ per thousand. cube. In 2020, the rising trend in world commodity prices, which are the main items of domestic exports (gold, natural gas, cotton), will cease and prices will stabilize in the following years.

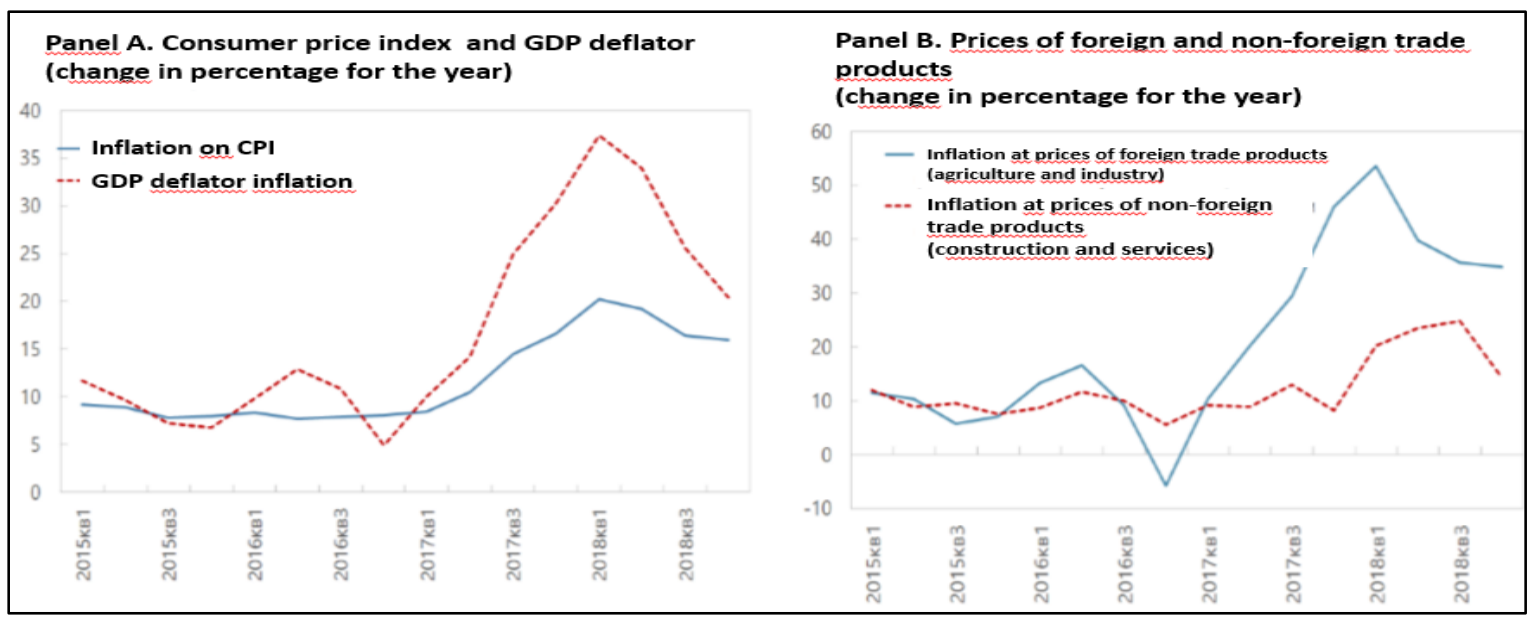

Figure 2 - Inflation of the Republic of Uzbekistan 2015-2019.

The liberalization of the currency market, the first steps towards price liberalization, the adjustment of the relative wages of public servants and the rapid growth of credit and domestic demand have had a strong, divergent effect on inflation since the reforms were initiated in 2018.

Reflecting the preponderance of the exchange rate depreciation effect, consumer price index (CPI) inflation reached a peak of 20 per cent in early 2019 , but retreated to 14 per cent by the end of the year. Expectations of high inflation remain steady, and alternative inflation indicators, especially GDP deflator, indicate high pressure from benchmark prices, with prices for foreign trade goods still rising to levels well above the CPI.

Potential risks and threats affecting sustainable economic development:
First, the development of the world economy will be accompanied by increased competition in global markets, which impose strict requirements for improving the efficiency of factors of production, including the accumulation and development of human capital $[28,29]$.

Secondly, the problem of employment, in the context of the rapidly growing labour force in Uzbekistan, requires the creation of favorable conditions for the organization of new productive capacities [30]. At the same time, the existing structural deformation of the country 's economy, characterized by the underdevelopment of the technological base of the main industries, the commodity direction of exports and the high share of agriculture in gross value added, the high size of the shadow economy, low productivity, high energy and 


\begin{tabular}{|c|c|c|c|c|c|c|}
\hline \multirow{4}{*}{ Impact Factor: } & ISRA (India) & $=4.971$ & SIS (USA) & $=0.912$ & ICV (Poland) & $=6.630$ \\
\hline & ISI (Dubai, UAE & $=0.829$ & РИНЦ (Russia & $=0.126$ & PIF (India) & $=1.940$ \\
\hline & GIF (Australia) & $=0.564$ & ESJI (KZ) & $=8.716$ & IBI (India) & $=4.260$ \\
\hline & JIF & $=1.500$ & SJIF (Morocce & $=5.667$ & OAJI (USA) & $=0.350$ \\
\hline
\end{tabular}

resource intensity, determines the long-term nature of the solution to the existing problems.

Thirdly, the accelerated introduction of effective instruments to ensure the functioning of the market economy is carried out, including the introduction of effective mechanisms for the protection of private property and the regulation of land relations, the improvement of the efficiency of State bodies, the eradication of corruption and the development of the financial market.

Fourthly, the country's economy is characterized by low levels of inclusiveness, accompanied by poor human capital quality, inequality in income distribution, weak social protection and scientific and technological potential, unsustainable use and depletion of natural resources.

Fifthly, the problems, as well as the shortcomings in ensuring an adequate material and technical base of the education system, are reflected in the low level of training and the territorial imbalance of demand in the personnel of various profiles. The weak relationship between scientific institutions and the real sector of the economy hinders the possibility of introducing innovation and adapting new technologies into production.

Sixth, the global environmental challenge and adverse long-term climate change resulting from the growth of industrialization, increased emissions, development of new natural resource deposits, as well as the depletion of the natural environment and water resources (including the reduction of sown areas and the decline in land fertility) are reflected in the adverse trend of climate change, which negatively affects the growth of disease levels, water supply and the development of the economy of Uzbekistan as a whole.

\section{Conclusion}

In addition, the legal framework and mechanisms for the implementation of laws and other legal acts remain inadequate in the sphere of economic relations regulation, and the system of public administration is dominated by direct instruments of regulation without an appropriate mechanism of responsibility and control over their application.

In 2020-2021, the economy will adapt to new conditions and market mechanisms through the implementation of adopted documents, which will affect the following tasks:

- $\quad$ ensuring macroeconomic stabilization;

- reforming of a system of preparation, retraining and increase in shots of shots for civil service;

- further development of institutional base of the market relations;

- development of education, sciences, health care, the ICT advancing investments into the human capital;

- restriction of corruption and decrease in level of shadow economy.

In conclusion, let us say that the forecast of GDP change indicators of the Republic of Uzbekistan for 2020-2021, that it is possible to maintain the ratio of gross savings to expenditures on final consumption of gross domestic product. The majority of the GDP of the Republic of Uzbekistan will be spent on final consumption in comparison with the gross accumulation of GDP of the Republic of Uzbekistan.

\section{References:}

1. Schumpeter, J. A. (1947). Theoretical problems of economic growth. The Journal of Economic History, 7(S1), 1-9.

2. Senghaas, D. (1991). Friedrich List and the basic problems of modern development. Review (Fernand Braudel Center), 451-467.

3. Clark, C. M. (1998). Thorstein Bunde Veblen: the quintessential dissenter. Economics and its Discontents, Twentieth Century Dissenting Economists. Cheltenham, UK: Edward Elgar, 267-282.

4. Galbraith, J. K., \& Kum, H. (2003). Inequality and economic growth: A global view based on measures of pay. CESifo Economic Studies, 49(4), 527-556.
5. Dosi, G., Cimoli, M., \& Stiglitz, J. E. (2009). The political economy of capabilities accumulation: The past and future of policies for industrial development. Mario Cimoli, Giovanni Dosi and Joseph E. Stiglitz.

6. Henry, J. F. (2016). John Bates Clark: the making of a neoclassical economist. Springer.

7. Keynes, J. M., \& Szmrecsanyi, T. (1978). John maynard keynes economia. Ática.

8. Domar, E. D. (1952). Economic growth: an econometric approach. The American Economic Review, 42(2), 479-495.

9. Harrod, R. F. (1958). Policy against inflation. Macmillan. 


\begin{tabular}{|c|c|c|c|c|c|c|}
\hline \multirow{4}{*}{ Impact Factor: } & ISRA (India) & $=4.971$ & SIS (USA) & $=0.912$ & ICV (Poland) & $=6.630$ \\
\hline & ISI (Dubai, UAE & $=0.829$ & РИНЦ (Russia & $=0.126$ & PIF (India) & $=1.940$ \\
\hline & GIF (Australia) & $=0.564$ & ESJI (KZ) & $=8.716$ & IBI (India) & $=4.260$ \\
\hline & JIF & $=1.500$ & SJIF (Morocce & $=5.667$ & OAJI (USA) & $=0.350$ \\
\hline
\end{tabular}

10. Merton, R. Colow. (1975). An asymptotic theory of growth under uncertainty. The Review of Economic Studies, 42(3), 375-393.

11. Nordhaus, W. D., \& Tobin, J. (1972). Economic growth (Vol. 5). National Bureau of Economic Res.

12. Nelson, R. R., \& Phelps, E. S. (1966). Investment in humans, technological diffusion, and economic growth. The American economic review, 56(1/2), 69-75.

13. Abalkin, L. (2001). Dinamika i protivorechiya ekonomicheskogo rosta. Ekonomist, (12), 3-10.

14. Bokov, V. V. (2015). Nauchno-metodologicheskie i institutsionalnyie aspektyi obespecheniya ustoychivogo razvitiya otraslevyih kompleksov. Problemyi ekonomiki i yuridicheskoy praktiki, (6).

15. Glazev, S. YU. (2012). Sovremennaya teoriya dlinnyih voln $\mathrm{v}$ razvitii ekonomiki. Ekonomicheskaya nauka sovremennoy Rossii, (2 (57)).

16. Koychuev T. K. (2011) Ekonomika Kyirgyizstana za 20 let suverennosti. Reforma. (50). 6-13.

17. Koshanov A.K., et al. (2007) Konkurentosposobnost natsionalnoy ekonomiki: kriterii otsenki i puti povyisheniya. Almatyi: Ekonomika.

18. Kushlin, V. I. (2004). Traektorii ekonomicheskih transformatsiy. Ekonomika.

19. Mikulskiy, K. I. (Ed.). (2002). Innovatsii i ekonomicheskiy rost. Nauka.

20. Rahimov A. M. (2019) Nekotoryie voprosyi effektivnosti strukturyi ekonomiki Respubliki Tadjikistan. Fundamentalnyie $i$ prikladnyie nauchnyie issledovaniya: aktualnyie voprosyi, dostijeniya i innovatsii. 73-75.

21. Tatarkin, A. I., \& Kotlyarova, S. N. (2013). Regionalnyie institutyi razvitiya kak faktoryi ekonomicheskogo rosta. Ekonomika regiona, (3 (35)).
22. Kadyirov, A. M., Sevlikyants, S. G., Otto, O. E., \& Ahmedieva, A. T. (2011). Informatsionnoinnovatsionnoe razvitie ekonomiki Uzbekistana. Monografiya. Iktisodiyot.

23. Rasulev, A. F., Pavlov, K. V., \& Baymuradov, SH. M. (2016). YAdro regionalnoy ekonomicheskoy sistemyi. Ekonomika i finansyi (Uzbekistan), (9).

24. Saidova, G. K. (2014). Uzbekistan vhodit v TOP5 stran mira, demonstriruyuschih vyisokie tempyi ekonomicheskogo rosta. Internet-jurnal. URL: http://economics. uzreport. uz/news_r_104348. html

25. CHepel, S. V., \& Bondarenko, K. A. (2015). YAvlyaetsya li vneshnyaya trudovaya migratsiya faktorom ekonomicheskogo rosta. Ekonometricheskiy analiz i vyivodyi dlya stran SNG. OF THE NEW ECONOMIC ASSOCIATION, 142.

26. Rasulev, A. F., \& Trostyanskiy, D. V. (2016). Uzbekistan: prioritetyi innovatsionnogo obespecheniya i tehnicheskogo obnovleniya promyishlennosti. CHasopis ekonomichnih reform, (2), 114.

27. (2020). Socio-economic situation of the Republic of Uzbekistan for january-december 2019. Goskomstat.

28. Kurpayanidi, K. I. (2018). The typology of factors of increasing the innovative activity of enterprise entrepreneurs in the industry. ISJ Theoretical \& Applied Science (10): 66.

29. Urmonov A. A. (2016). Modern trends in the further development of the Shanghai Cooperation Organization (SCO) in the context of globalization. Young Scientist. (17): 4.

30. Kurpayanidi, K. I. (2019). Actual issues of activation of foreign economic activity in the economy of Uzbekistan. ISJ Theoretical \& Applied Science, 04 (72), 60-65 